\title{
Correction: Noguerol-Pato, R., et al. Effect on the Aroma Profile of Graciano and Tempranillo Red Wines of the Application of Two Antifungal Treatments onto Vines. Molecules 2014, 19, 12173-12193
}

Raquel Noguerol-Pato, Thais Sieiro-Sampedro, Carmen González-Barreiro, Beatriz Cancho-Grande and Jesús Simal-Gándara *

Group of Nutrition and Bromatology, Department of Analytical and Food Chemistry, Faculty of Food Science and Technology, University of Vigo, Ourense E-32004, Spain

* Author to whom correspondence should be addressed; E-Mail: jsimal@uvigo.es;

Tel.: +34-988-387-060; Fax: +34-988-387-001.

Received: 16 October 2014 / Accepted: 20 October 2014 / Published: 29 October 2014

The authors wish to make the following correction to paper [1], doi:10.3390/molecules190812173, website: http://www.mdpi.com/1420-3049/19/8/12173.

The author name "Thais Sieiro-Sampredro" should be "Thais Sieiro-Sampedro".

We have detected an error in the results expression units, and the decimal "." has to be moved 1 position, resulting in a factor of 10 . The corrected data were provided in the new version of the Table 3 (under column B).

Table 3. Commercial formulations used in open-field treatments.

\begin{tabular}{|c|c|c|c|}
\hline Wine & $\mathbf{A}^{\mathbf{a}}$ & $\mathbf{B}$ & C \\
\hline Commercial name & - & Collis & Vivando \\
\hline Fungicide formulation & - & $20 \%$ boscalid $+10 \%$ kresoxim-methyl & $50 \%$ metrafenone \\
\hline Fungal disease & - & Grey mold and powdery mildew & Powdery mildew \\
\hline $\begin{array}{l}\text { Fungicide concentration in } \\
\text { Tempranillo grapes }(\mathrm{mg} / \mathrm{Kg}){ }^{b}\end{array}$ & - & $1.5+0.54$ & 2.8 \\
\hline $\begin{array}{l}\text { Fungicide concentration in Graciano } \\
\text { grapes }(\mathrm{mg} / \mathrm{Kg})^{b}\end{array}$ & - & $2.2+0.82$ & 1.5 \\
\hline $\begin{array}{l}\text { Residual concentrations of fungicides } \\
\text { in Tempranillo wines }(\mu \mathrm{g} / \mathrm{L})^{\mathrm{b}}\end{array}$ & - & $109+39$ & 197 \\
\hline $\begin{array}{l}\text { Residual concentrations of fungicides } \\
\text { in Graciano wines }(\mu \mathrm{g} / \mathrm{L})^{b}\end{array}$ & - & $155+59$ & 107 \\
\hline
\end{tabular}

Notes: ${ }^{\mathrm{a}}$ Control treatment; ${ }^{\mathrm{b}}$ Concentrations were determined following the method proposed by Lagunas-Allué et al. [43]. 


\section{Reference}

1. Noguerol-Pato, R.; Sieiro-Sampredro, T.; González-Barreiro, C.; Cancho-Grande, B.; Simal-Gándara, J. Effect on the aroma profile of Graciano and Tempranillo red wines of the application of two antifungal treatments onto vines. Molecules 2014, 19, 12173-12193.

(C) 2014 by the authors; licensee MDPI, Basel, Switzerland. This article is an open access article distributed under the terms and conditions of the Creative Commons Attribution license (http://creativecommons.org/licenses/by/4.0/). 